CARACTERIZACIÓN Y COMPORTAMIENTO BIMENSUAL DE LA COMUNIDAD SÉSIL ASOCIADA CON EL LITORAL ROCOSO DE BOCACHICA, ISLA DE TIERRA BOMBA, CARIBE COLOMBIANO

\title{
BIMONTHLY CHARACTERIZATION AND BEHAVIOR OF THE SESSILE COMMUNITY ASSOCIATED WITH THE ROCKY LITTORAL OF BOCACHICA, TIERRA BOMBA ISLAND, COLOMBIAN CARIBBEAN
}

\author{
Samuel G. Núñez ${ }^{1}$ \\ Nancy H. López ${ }^{1}$ \\ Camilo B. García ${ }^{2}$ \\ Gabriel R. Navas ${ }^{1}$ \\ ${ }^{1}$ Instituto de Investigaciones Marinas y Costeras de Punta de Betín \\ "José Benito Vives de Andreis" (INVEMAR) \\ Apartado Aéreo 1016 \\ Cerro de Punta de Betín \\ Santa Marta, Colombia \\ ${ }^{2}$ Universidad Nacional de Colombia \\ INVEMAR \\ Apartado Aéreo 1016 \\ Cerro de Punta de Betín \\ Santa Marta, Colombia
}

Recibido en noviembre de 1998; aceptado en junio de 1999

\section{RESUMEN}

Sobre el litoral rocoso de Bocachica, Isla de Tierra Bomba, Caribe colombiano, se muestrearon diez transectos fijos bimensualmente durante un año con el método transecto/cadena para describir la variación temporal de la estructura comunitaria. La comunidad presentó un patrón de zonación similar al encontrado en el resto del Caribe. Las especies características fueron el molusco vermétido Dendropoma corrodens y la esponja Tedania ignis en el mesolitoral, y las algas coralináceas Peyssonnelia sp. y el morfotipo 1 en el infralitoral. Las restantes 54 especies fueron menos abundantes y en su mayoría ocasionales. Se encontró un factor ambiental de disturbio ocasionado por el desplazamiento de la planicie arenosa adyacente, el cual estuvo representado en un patrón de cambio temporal del ancho de las zonas que no pareció presentar una relación con la pluviosidad, inclinación del sustrato, ni el régimen predominante de vientos y corrientes. La fluctuación relativa en el ancho de las zonas, de mayor a menor, se presentó en el supra, infra y mesolitoral. El análisis de ordenación y clasificación de los transectos en cada muestreo mostró un patrón espacial que sugiere la existencia de un gradiente ambiental debido posiblemente a la exposición diferencial al viento y oleaje. La comunidad de uno de los transectos fue claramente diferente a los demás, al parecer debido a su mayor pendiente y grado de exposición al oleaje y corrientes. Las clasificaciones y ordenaciones realizadas entre las diferentes fechas mostraron una variación temporal relacionada con el régimen climático. Se encontró un desplazamiento escalonado de la 
comunidad de los muestreos de mayo a noviembre (época de lluvias), mientras que los muestreos de enero a mayo (época seca y principios de lluvias) conforman un grupo separado. Finalmente, se observó un cambio de la comunidad de un año al inicio del otro.

Palabras clave: litoral rocoso, comunidades sésiles, Caribe colombiano, variación temporal.

\begin{abstract}
A total of ten fixed transects were sampled at two-month intervals during one year at the rocky littoral of Bocachica, Tierra Bomba Island, Colombian Caribbean. The census technique used was the transect-chain method. The zonation pattern observed was similar to that of other Caribbean locations. The characteristic species of the mesolittoral were the vermetid Dendropoma corrodens and the sponge Tedania ignis. The characteristic species of the infralittoral were the corallinacea alga Peyssonnelia $\mathrm{sp}$. and one undetermined species (morphotype 1). The other 54 species were less abundant and occasional. A disturbance factor was found consistent with the advance and withdrawal of the sand plane on the sublittoral, which clearly affected the width of the littoral zones. This perturbation had no correlation with rain or the current regime, but it had a weak one with substrate inclination. The relative fluctuation in the width of the zones was highest in the supralittoral and lowest in the mesolittoral. The spatial classification and ordination analyses of the transects showed a spatial pattern dependent on the differential grade of exposure to the wind and waves. This was particularly notorious in one of the steepest and most exposed transects. The temporal classification and ordination of the transects showed an ordered pattern of change clearly correlated with the sampling month. The monthly samplings corresponding to the rainy season (May to November) and the monthly samplings corresponding to the dry season (January to May) revealed two distinct groups. The last sampling month (May) was placed apart from the initial sampling month (May of the previous year), which suggests a cycle longer than one year.
\end{abstract}

Key words: rocky littoral, sessile communities, Colombian Caribbean, temporal change.

\section{INTRODUCCIÓN}

Los litorales rocosos del Atlántico occidental y en particular del Mar Caribe, al igual que otros litorales rocosos del mundo, presentan una zonación caracterizada por una zona supralitoral que está siempre emergida, una zona mesolitoral expuesta a la acción del oleaje y las mareas, y una zona infralitoral que permanece en continua inmersión (Stephenson y Stephenson, 1949; Vegas-Vélez, 1971; Taylor, 1978). Esta zonación depende principalmente de factores como el régimen climático, energía del viento y del oleaje, profundidad, intensidad lumínica, movimiento del agua, topografía del fondo y presión por herviborismo, entre otros (Hoeck et al., 1978; Thomas, 1985; Eston et al., 1986).

Los estudios sobre las comunidades de litorales rocosos del Caribe colombiano se han centrado únicamente en algunos componentes,

\section{INTRODUCTION}

Similar to other rocky shores throughout the world, the rocky shores of the western Atlantic and, in particular of the Caribbean Sea, have a zonation characterized by a supralittoral zone that is always emerged, a mesolittoral zone that is exposed to wave action and tides, and an infralittoral zone that is always submerged (Stephenson and Stephenson, 1949; Vegas-Vélez, 1971; Taylor, 1978). This zonation is mainly dependent on climate, energy of the wind and waves, depth, light intensity, water movement, bottom topography and pressure from herbivores, among other factors (Hoeck et al., 1978; Thomas, 1985; Eston et al., 1986).

Studies of the rocky-shore communities of the Colombian Caribbean have only focussed on certain components, such as algae (Gaviria, 1977; Guillot and Márquez, 1978; Márquez and Guillot, 
como los de las algas (Gaviria, 1977; Guillot y Márquez, 1978; Márquez y Guillot, 1983), moluscos (Díaz y Puyana, 1994; Gutiérrez, 1994; Bandel y Wedler, 1987) y cnidarios (hidroides) (Bandel y Wedler, 1987). Sólo el trabajo de Brasttström (1980) describe la zonación de toda la comunidad. Los estudios encaminados a describir el comportamiento dinámico de dichas comunidades se limitan a Zea (1993a, b), quien describió las comunidades presentes en un litoral rocoso en la zona de Santa Marta y estudió el reclutamiento de esponjas, y Schoppe (1990, 1996), quien se centró en la misma área y estudió a las comunidades de erizos del género Echinometra y sus relaciones simbióticas.

En este trabajo se presenta una evaluación a pequeña escala espacial (200 m de línea de costa) de la comunidad de organismos asociada con un litoral basado sobre roca coralina fósil en Bocachica, Isla de Tierra Bomba, sector de Cartagena. Se caracteriza la comunidad en términos de su composición y zonación, y se describe el comportamiento de estos dos componentes a lo largo del ciclo anual.

\section{ÁREA DE ESTUDIO}

El litoral rocoso estudiado (fig. 1) corresponde a un sector del litoral suroccidental de la Isla de Tierra Bomba. La isla se ubica frente a la Bahía de Cartagena, entre los $10^{\circ} 32^{\prime}$ y $10^{\circ} 19^{\prime} \mathrm{N}$ y $75^{\circ} 23^{\prime}$ y $75^{\circ} 36^{\prime} \mathrm{W}$, y está basada sobre estructuras de origen coralino del Pleistoceno que emergieron por la dinámica de las transgresiones y regresiones marinas (Plagiardini et al., 1982; Le Blé y Cuignon, 1987). El sector evaluado está caracterizado por tener una topografía bastante irregular, con pendientes desde muy bajas y horizontales hasta casi verticales.

La zona de estudio se halla ubicada en la zona de convergencia tropical que regula su patrón climático, presentándose una época seca (diciembre a abril), con predominio de vientos alisios del N-NE, y una época húmeda o de lluvias (mayo a noviembre), con vientos de baja intensidad y aumento en las lluvias (Plagiardini et al., 1982;
1983), mollusks (Díaz and Puyana, 1994; Gutiérrez, 1994; Bandel and Wedler, 1987) and cnidarians (hydroids) (Bandel and Wedler, 1987). Only the work of Brattström (1980) describes the zonation of the entire community. The studies that describe the dynamic behavior of these communities include those of Zea (1993a, b), who described the communities present in a rocky shore around Santa Marta and studied sponge recruitment, and Schoppe (1990, 1996), who studied the sea urchin communities of the genus Echinometra and their symbiotic relationships in the same area.

This work presents an evaluation of small spatial scale (200 m of coast line) of the community of organisms associated with a littoral of fossil coralline rock in Bocachica, Tierra Bomba Island, Cartagena. The community is described in terms of its composition and zonation, and the behavior of these two components is described during one year.

\section{STUDY AREA}

The rocky shore studied (fig. 1) corresponds to a section of the southwestern shore of Tierra Bomba Island. The island is located off Cartagena Bay, between $10^{\circ} 32^{\prime}$ and $10^{\circ} 19^{\prime} \mathrm{N}$ and $75^{\circ} 23^{\prime}$ and $75^{\circ} 36^{\prime} \mathrm{W}$, and is made up of coralline structures from the Pleistocene that emerged during transgressions and regressions of the sea (Plagiardini et al., 1982; Le Blé and Cuignon, 1987). The study area has an irregular topography, with slopes from very low and horizontal to almost vertical.

The study area is located in a zone of tropical convergence that regulates the climate pattern: a dry season (December to April), with dominant trade winds from the N-NE, and a rainy season (May to November), with low-intensity winds (Plagiardini et al., 1982; Le Blé and Cuignon, 1987). The climate of the island varies from Dry Tropical Forest to Very Dry Tropical Forest, with an average temperature of $27.9 \pm 2{ }^{\circ} \mathrm{C}$ and a multiannual average rainfall of $74 \mathrm{~mm}$ (Plagiardini et al., 1982; Le Blé and Cuignon, 1987; HIMAT, 1995). 

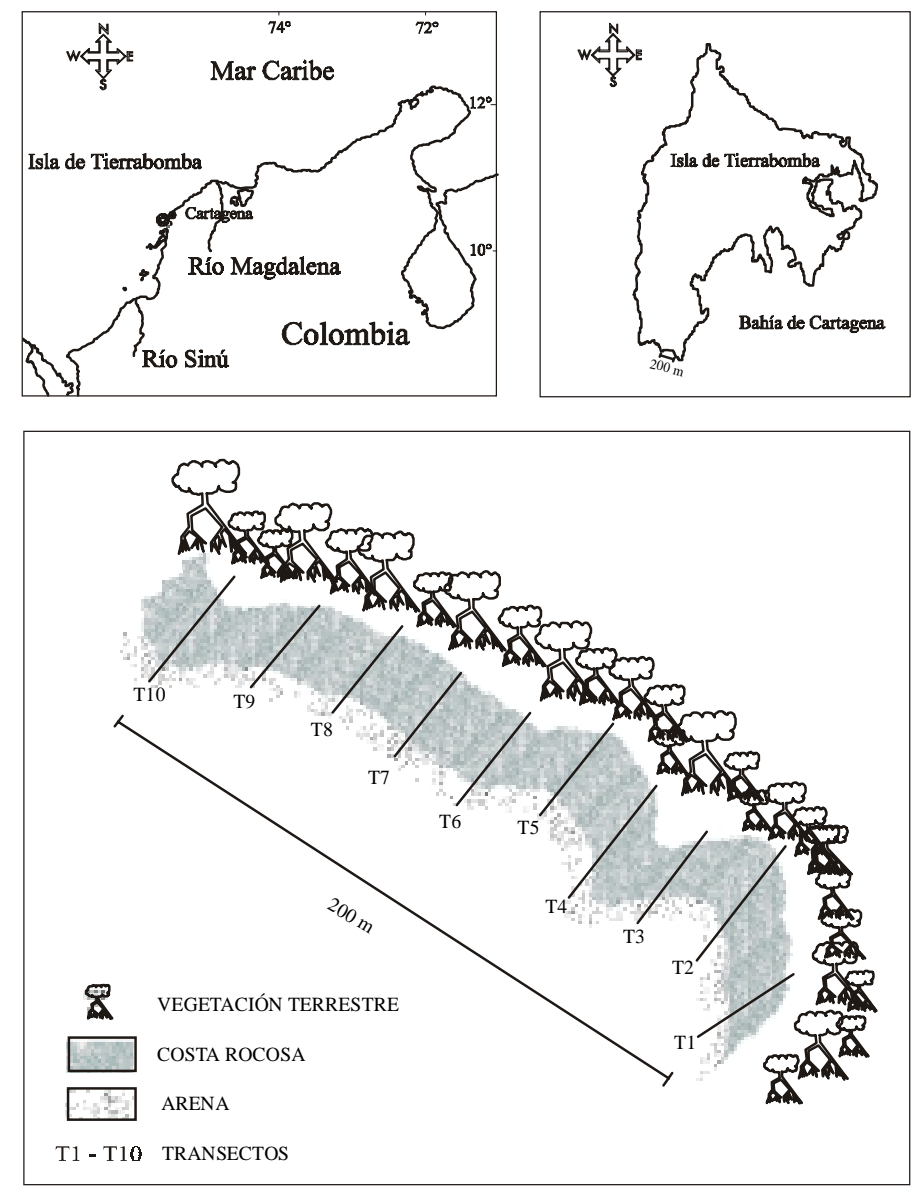

Figura 1. Ubicación del área de estudio.

Figure 1. Location of the study area.

Le Blé y Cuignon, 1987). La isla está sujeta a un clima de Bosque Seco Tropical a Bosque Muy Seco Tropical, y se caracteriza por tener una temperatura ambiental promedio de $27.9 \pm 2^{\circ} \mathrm{C}$ y una precipitación promedio multianual de $74 \mathrm{~mm}$ (Plagiardini et al., 1982; Le Blé y Cuignon, 1987; HIMAT, 1995).

La circulación de las aguas en la región está afectada principalmente por la corriente del Caribe, engendrada por los vientos alisios con dirección sur, y la contracorriente del Darién (Panamá), que fluye en dirección opuesta a la
The water circulation of the area is defined by the Caribbean current, driven by trade winds with a southward direction, and the Darién countercurrent (Panama), that flows in the opposite direction. During the most intense period of the rainy season (October), the waters move from the bay to the study area for many days, due to an increase in the flow of water from the Canal del Dique to Cartagena Bay and a decrease in wind intensity, producing a turbid plume $1-1.5 \mathrm{~m}$ deep below which the water is clear. In the dry season, there is a daily discharge of water from Cartagena Bay to 
anterior. En la parte más intensa del periodo de lluvias (octubre), debido al aumento del flujo de agua del Canal del Dique hacia la Bahía de Cartagena y la disminución en la intensidad del viento, las aguas salen de la bahía hacia la zona estudiada por varios días consecutivos, produciendo una pluma de turbidez de 1 a $1.5 \mathrm{~m}$ de profundidad bajo la cual el agua es transparente. En la época seca, se presenta un ciclo diario de descarga de agua de la Bahía de Cartagena hacia mar abierto llamado "bombazo", que produce turbidez en el agua por espacio de una hora aproximadamente hacia el medio día.

Para Bocachica, y en general para la Bahía de Cartagena, se cuenta con una marea semidiurna, con un rango de variación de 17 a $42 \mathrm{~cm}$ (Plagiardini et al., 1982; Le Blé y Cuignon, 1987).

\section{MATERIALES Y MÉTODOS}

El estudio tuvo una duración de un año, con una campaña de muestreo cada dos meses que comenzó en mayo de 1993 y terminó en mayo de 1994.

En una primera visita se realizó un reconocimiento visual por medio de nado libre para establecer y delimitar la extensión del área de estudio por unidades paisajísticas. En el área elegida se extendió un cabo guía de $200 \mathrm{~m}$ paralelo a la línea de costa sobre el cual se ubicaron 10 transectos perpendiculares a éste. Para la evaluación de los transectos se extendió una cadena con eslabones de $3.1 \mathrm{~cm}$ de longitud (16 eslabones equivalen a $50 \mathrm{~cm}$ ), teniendo en cuenta que siempre estuviera en contacto con el sustrato (CARICOMP, 1990; Zea, 1993a; Rogers et al., 1994). La cadena se fijó con estacas de acero de $1.3 \mathrm{~cm}$ de diámetro, las cuales se usaron como marcas para efectuar los siguientes muestreos (Baker y Crothers, 1987). Se registró el número de eslabones correspondiente a cada componente bentónico recorrido sistemáticamente por la cadena, con base en la metodología de CARICOMP (1990) para arrecifes coralinos. the open ocean that causes the water to become turbid for about an hour around noon.

In general, both Bocachica and Cartagena Bay have a semidiurnal tide with a range that varies from 17 to $42 \mathrm{~cm}$ (Plagiardini et al., 1982; Le Blé and Cuignon, 1987).

\section{MATERIALS AND METHODS}

The study lasted one year and consisted of bimonthly samplings that began in May 1993 and ended in May 1994.

A preparatory visit was made to visually inspect the study area and to establish and delimit the area based on landmarks. A 200-m guide rope was placed parallel to the coastline in the area selected and this was used to establish 10 perpendicular transects. In order to evaluate the transects, a chain with links $3.1 \mathrm{~cm}$ long was hung (16 links equal $50 \mathrm{~cm}$ ), taking care that it was in constant contact with the bottom (CARICOMP, 1990; Zea, 1993a; Rogers et al., 1994). The chain was fixed with steel stakes $1.3 \mathrm{~cm}$ in diameter that were used as markers during the samplings (Baker and Crothers, 1987). The number of links corresponding to each benthic component systematically observed on the chain was recorded, based on the methods of CARICOMP (1990) for coral reefs. During the first sampling, bathymetric measurements were made every $50 \mathrm{~cm}$ in each transect and samples were taken of the organisms, which were preserved for identification in the laboratory.

The relationship between the total number of links that represented each benthic component and the total number of links evaluated was used to determine the percent cover (chain) of each component (CARICOMP, 1990; Foster et al., 1991; Meese and Tomich, 1992).

In order to delimit and describe the zonation, the data of each transect were divided every $50 \mathrm{~cm}$ and the percent cover of each benthic component was calculated for each division. Using these data, a classification analysis of the divisions was made with the Bray-Curtis dissimilarity index, using data transformed with the 
Ciencias Marinas, Vol. 25, No. 4, 1999

En el primer muestreo se hicieron mediciones batimétricas cada $50 \mathrm{~cm}$ en cada transecto y se tomaron muestras de organismos que fueron preservadas y guardadas para su posterior identificación en el laboratorio.

La relación entre el número total de eslabones en los que estaba representado cada componente bentónico y el número total de eslabones evaluados se empleó para determinar el porcentaje de cobertura (cadena) de cada componente (CARICOMP, 1990; Foster et al., 1991; Meese y Tomich, 1992).

Para delimitar y caracterizar la zonación, los datos de cada transecto fueron divididos cada $50 \mathrm{~cm}$ y se calculó para cada división el porcentaje de cobertura de cada componente bentónico. Empleando estos datos se realizó un análisis de clasificación entre divisiones empleando el índice de disimilaridad de Bray-Curtis, con datos transformados con la función $\log _{\mathrm{x}+1}$ (Clarke $\mathrm{y}$ Warwick, 1994). La descripción final de la zonación del transecto corresponde a los grupos de divisiones que se detectaron en los dendrogramas obtenidos. Para caracterizar los grupos de especies de cada zona se realizó un análisis inverso siguiendo la estrategia propuesta por Kaandorp (1986), clasificando las especies como exclusivas (100\% presentes en una zona) y características (abundancia relativa $>70 \%$ y frecuencia de aparición $>67 \%$ ). Se describió el comportamiento temporal de las especies como permanentes y no permanentes, adoptando el criterio de autores como Boero y Fresi (1986), Ojeda y Dearborn (1989) y Hill y Hawkins (1991).

La dinámica del ancho de las diferentes zonas fue descrita para cada transecto graficando la longitud de cada una de ellas en cada fecha de muestreo. El patrón de variación espacial de los transectos por fecha de muestreo se describió con base en un análisis de ordenación (NMDS), con datos de porcentaje de cubrimiento transformados mediante $\log _{\mathrm{x}+1}$ (Clarke y Warwick, 1994), y el patrón de las fechas de muestreo se describió mediante un análisis de clasificación, empleando el índice de similaridad de Bray-Curtis y un NMDS. $\log _{x+1}$ function (Clarke and Warwick, 1994). The last description of the zonation of the transect corresponds to the groups of divisions detected in the dendrograms obtained. In order to characterize the groups of species from each zone, an inverse analysis was made, following the method of Kaandorp (1986), which classifies the species as exclusive ( $100 \%$ presence in a zone) and characteristic (relative abundance $>70 \%$ and frequency of occurrence $>67 \%$ ). The temporal behavior of the species was described as permanent or not permanent, based on the criterion of Boero and Fresi (1986), Ojeda and Dearborn (1989) and Hill and Hawkins (1991).

The dynamics of the width of the different zones was described for each transect. The length of each transect was plotted for each sampling date. The pattern of spatial variation of the transect per sampling date was determined with an ordination analysis (NMDS), using the data of percent cover transformed with $\log _{\mathrm{x}+1}$ (Clarke and Warwick, 1994). The pattern of the sampling dates was determined with a classification analysis, using the Bray-Curtis similarity index and NMDS.

\section{RESULTS AND DISCUSSION}

\section{Zonation}

The classification analysis of the divisions of each transect established a zonation with conspicuous limits (fig. 2), represented by horizontal lines that reflect the strong linear nature of the environmental factors.

These zones adhere to the global scheme of supra-, meso- and infralittoral proposed by Stephenson and Stephenson (1949) and mentioned by Brattström (1980) and Bandel and Wedler (1987) for Santa Marta in the Colombian Caribbean.

Only organisms that tolerate constant emergence were observed in the supralittoral, the mollusks being characteristic of the group of the Littorina, which were not included in the samplings. 


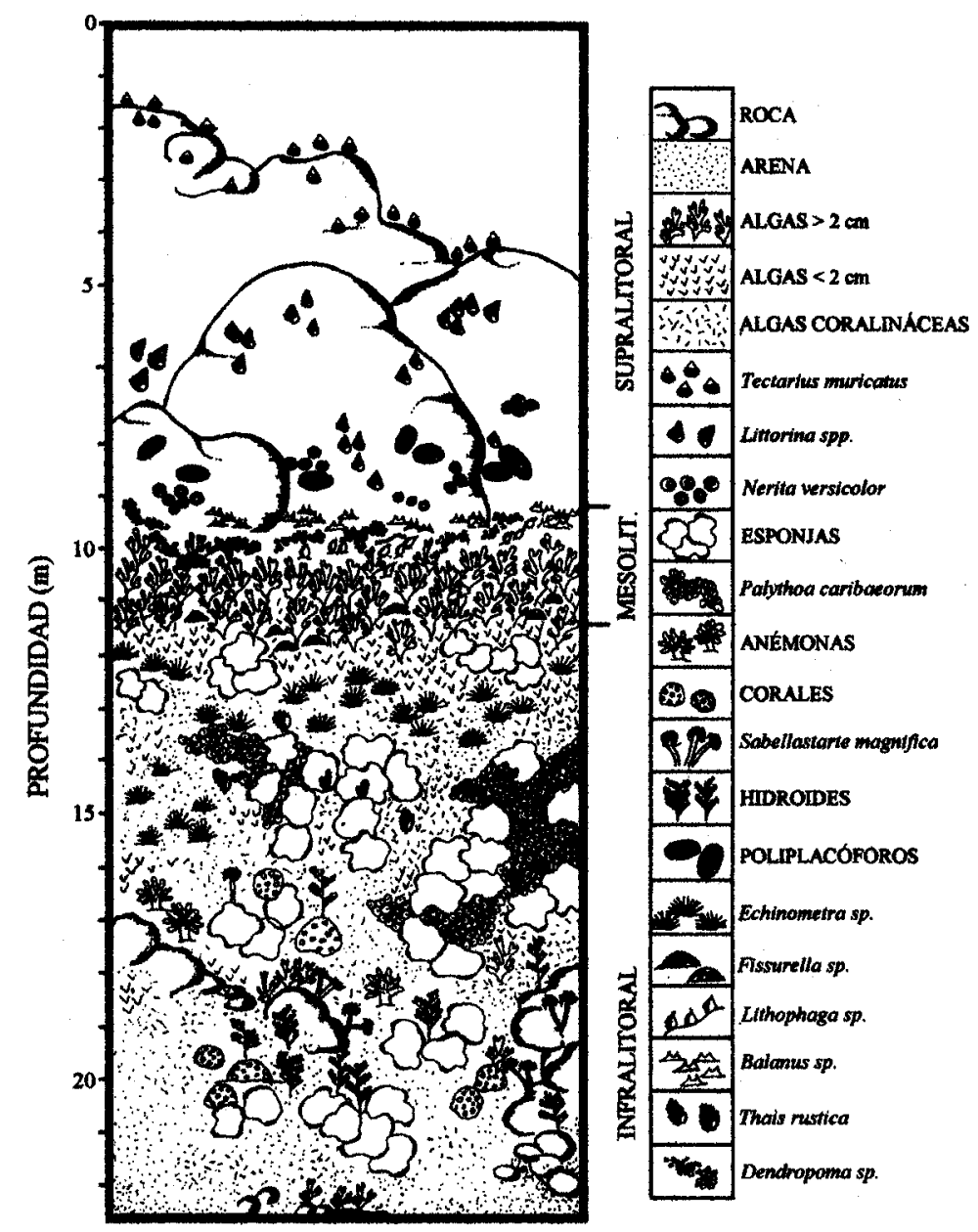

Figura 2. Representación gráfica de la comunidad litoral encontrada en un transecto típico.

Figure 2. Graphic representation of the littoral community found in a typical transect.

\section{RESULTADOS Y DISCUSIÓN}

\section{Zonación}

Los análisis de clasificación realizados entre divisiones de cada transecto permitieron establecer una zonación con límites conspicuos (fig. 2), representados por líneas horizontales que reflejan
The organisms observed in the mesolittoral have adapted to conditions of submergence/ emergence and to the wave action; in the upper part, the vermetid mollusk Dendropoma sp. dominated (96\%), causing the bottom to become porous. Cyanophyceous algae grow on top of the vermetids and provide the characteristic green color of the supralittoral and upper part of the 
Ciencias Marinas, Vol. 25, No. 4, 1999

una fuerte naturaleza lineal de los factores ambientales.

Estas zonas se ajustan al esquema global de supra, meso e infralitoral propuesto por Stephenson y Stephenson (1949) y mencionado por Brattström (1980) y Bandel y Wedler (1987) para la zona de Santa Marta en el Caribe colombiano.

En el supralitoral, sólo se presentaron organismos que soportan emersión continua, siendo característicos los moluscos del grupo de las litorinas, las cuales no quedaron incluidas en los muestreos mediante cadena.

En el mesolitoral se encontraron organismos adaptados a condiciones de inmersión/emersión y al golpe del oleaje; en su parte superior abundaron las galerías del molusco vermétido Dendropoma sp. (96\%) que ocasionan que el sustrato se vuelva poroso. Sobre estos vermétidos crecen algas cianofitas que le imparten el color verdoso característico al supralitoral y a la parte superior del mesolitoral. La parte inferior del mesolitoral presentó un tapete de algas entremezcladas, especialmente Laurencia sp. y Gelidium sp. (4\%), y otros organismos no muy abundantes asociados con ellas.

En el infralitoral se encontraron especies adaptadas a condiciones de inmersión continua, destacándose las algas (Galaxaura sp.) con $60 \%$ de cobertura, seguidas por las esponjas con $32 \%$ y los celenterados con $5 \%$. El resto estuvo representado por grupos como moluscos, poliquetos y equinoideos (tabla 1). La ausencia de una franja de cirripedios, como la que menciona Brattström (1980) en el mesolitoral de la región de Santa Marta, así como las diferencias en las especies por él encontradas deben ser el resultado de varios factores, entre los que se pueden mencionar: el continuo aporte de aguas salobres a que está sometido Bocachica; el tipo de sustrato, i.e., coral fósil en Bocachica en contraste con roca volcánica en Santa Marta; y el fenómeno de surgencia que afecta a la región de Santa Marta (Bula, 1977, 1985).

Los porcentajes de cobertura de los grupos de organismos encontrados en el infralitoral de mesolittoral. In the lower mesolittoral, there is a carpet of intermixed algae, mainly Laurencia sp. and Gelidium sp. (4\%) and other associated organisms that are not very abundant.

The species observed in the infralittoral have adapted to conditions of continuous submergence. The most dominant species were algae (Galaxaura sp.) with $60 \%$ cover, followed by sponges with $32 \%$ and coelenterates with $5 \%$. The remaining species consisted of groups of mollusks, polychaetes and echinoids (table 1). The absence of the strip of cirripeds reported by Brattström (1980) for the mesolittoral of Santa Marta, as well as differences in the species observed by this author may be due to many factors, such as a continuous supply of salt water to Bocachica; type of bottom, i.e., fossil coral in Bocachica compared to volcanic rock in Santa Marta; and upwelling that affects the area of Santa Marta (Bula, 1977, 1985).

The cover percentages of the groups of organisms found in the infralittoral of Bocachica were similar to those found by Zea (1993a) for a rocky infralittoral with coralline characteristics outside Santa Marta Bay. This author found that close to $60 \%$ of the bottom was covered by a carpet of algae (crustose, filamentous and thalloid) and the rest by sponges, scleractinian corals and other animals. This author confirms that differences in light and the sediment trapped with respect to the slope of the bottom are the principal factors that explain the high algal cover on open bottoms (horizontal to sloped) on shallow, rocky shores and the high occurrence of sponges and corals on cryptic bottoms (semivertical to vertical). This phenomenon is similar to that observed for the horizontal, semivertical and vertical surfaces of the rocky shore of this study.

The higher abundance of macroalgae than of sponges, and of the latter than of other groups, is due to the dissolved organic and inorganic matter and/or the suspended matter transported by the upper turbidity layer from Cartagena Bay, which provides nutrients for these organisms. The particles deposited on the surface of the littoral and the organisms, as well as the low abundance 
Bocachica fueron similares a los encontrados por Zea (1993a) en un infralitoral rocoso de características coralinas en las afueras de la Bahía de Santa Marta. Dicho autor encontró que cerca del $60 \%$ del sustrato estaba cubierto por un tapete de algas (costrosas, filamentosas y talosas) y el resto lo representaban esponjas, corales escleractíneos y otros animales. Este autor afirma que las diferencias en iluminación ambiental y sedimento atrapado según la inclinación del sustrato son los principales factores que pueden explicar la mayor cobertura de algas en el litoral rocoso somero en sustrato abierto (horizontal a inclinado) y la mayor presencia de esponjas y corales en sustrato críptico (vertical a extraplomado). Este fenómeno es similar al observado en las superficies horizontales, verticales y extraplomadas del litoral rocoso estudiado.

La abundancia de macroalgas más que de esponjas, y de estas últimas más que de otros grupos, debe ser al menos en parte el reflejo de la materia orgánica e inorgánica disuelta y/o en suspensión arrastrada por la capa superior de turbidez proveniente de la Bahía de Cartagena, la cual podría proporcionar nutrientes a estos organismos. Las partículas depositadas sobre la superficie del litoral y de los organismos, así como la poca abundancia de corales y la presencia de especies con una alta resistencia a la sedimentación, como Diploria clivosa (Prahl y Erdhardt, 1985), evidencian que esta capa turbia podría estar aportando al sistema una cantidad importante de sedimentos. Los ejemplares encontrados de esponjas crecen con poca altura y adheridos al sustrato, lo cual, al parecer, está en relación directa con condiciones de alta energía en el agua por acción del oleaje y/o corrientes (Zea, 1987).

La estructura básica del litoral estudiado está sustentada por las especies más frecuentes y abundantes, y los cambios espaciales y temporales que se encontraron y se describen posteriormente se deben principalmente a la reacomodación de este grupo de especies en términos de su abundancia (cubrimiento) relativa. En la tabla 1 se observa como los organismos permanentes $(\mathrm{P})$ presentan una alta cobertura a lo largo de todo el año, en of corals and the occurrence of species that are highly resilient to sedimentation, such as Diploria clivosa (Prahl and Erdhardt, 1985), indicate that this turbid layer may contribute an important amount of sediments to the system. The sponge specimens found are short and attached to the bottom, apparently in direct response to the highenergy conditions of the water caused by the wave action and/or currents (Zea, 1987).

The basic structure of the littoral studied is sustained by the most frequent and abundant species, and the spatial and temporal changes observed are mainly due to the rearrangement of these species in terms of their relative abundance (cover). Table 1 shows how the permanent (P) organisms present a high cover throughout the year, whereas the species with a low frequency (not permanent $[\mathrm{NP}]$ ) show a varying temporal behavior. It is also observed that characteristic species of one zone temporarily occupy neighboring zones, for example: Dendropoma sp. of the mesolittoral; and Tedania ignis (Duchassaing and Micheloti, 1864), the incrusted rose coralline Peyssonnelia sp., Amphimedon viridis Duchassaing and Micheloti, 1864, and Plakospongia melobesioides (Ellis and Solander, 1786) of the infralittoral.

\section{Disturbance regimen}

During the study, it was very clear that the disturbance of the littoral system was expressed as changes in the width of the zones.

The graph of the transect widths per zone in the samplings (fig. 3) shows an average variation of the infralittoral of $1178 \pm 342 \mathrm{~cm}$, of the supralittoral of $607 \pm 351 \mathrm{~cm}$ and of the mesolittoral of $100 \pm 32.5 \mathrm{~cm}$. The most variable lengths observed among transects were: supralittoral, coefficient of variation $(\mathrm{cv})=0.58$; mesolittoral, $\mathrm{cv}=0.35$; and infralittoral, $\mathrm{cv}=$ 0.29 .

The variation in width of the supralittoral mainly follows the migration of the upper limit of the mesolittoral, whereas the variation in width of the infralittoral is due to the migration of the 
Ciencias Marinas, Vol. 25, No. 4, 1999
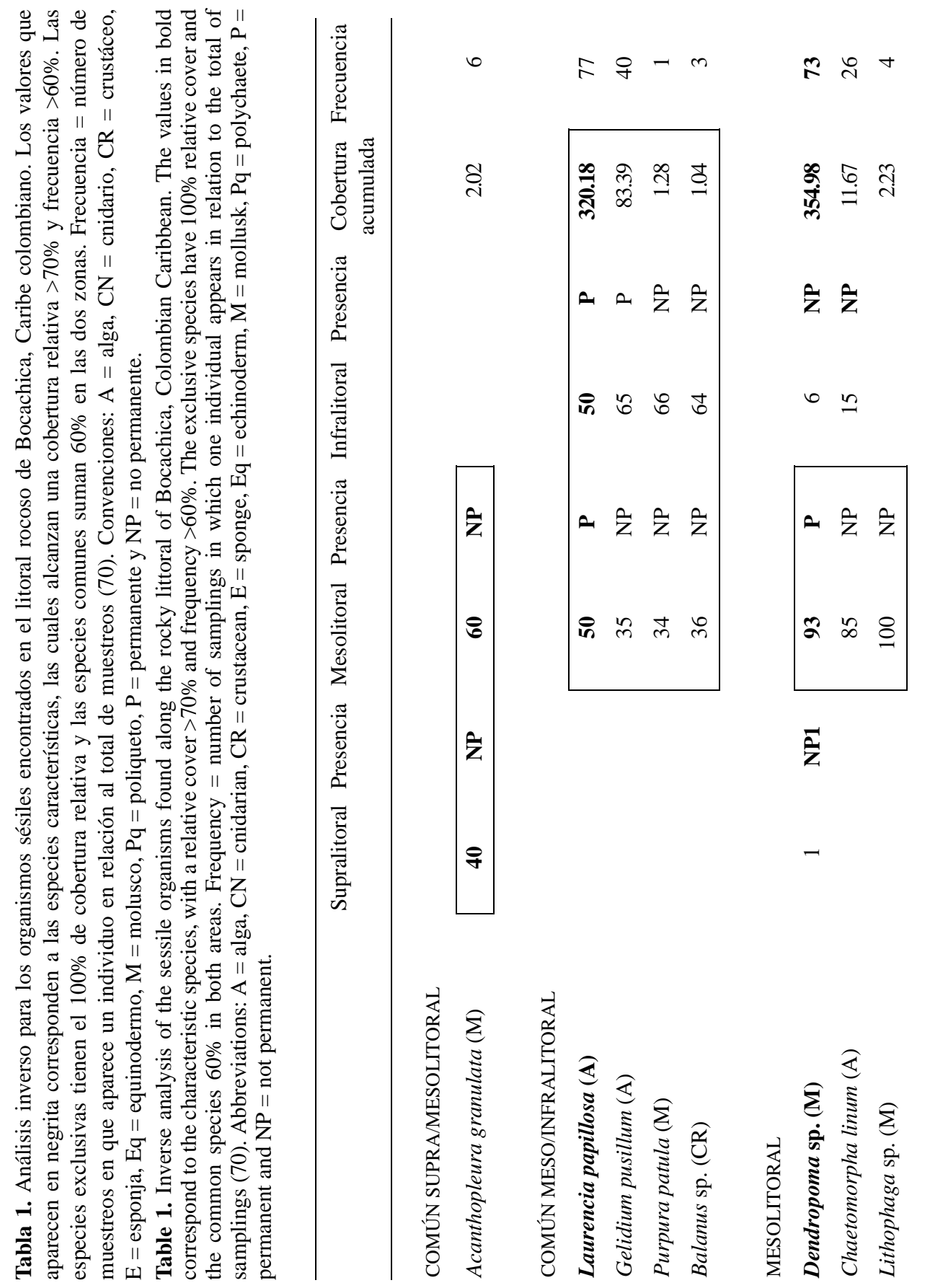
Núñez et al:: Variación temporal de la comunidad sésil en un litoral rocoso tropical

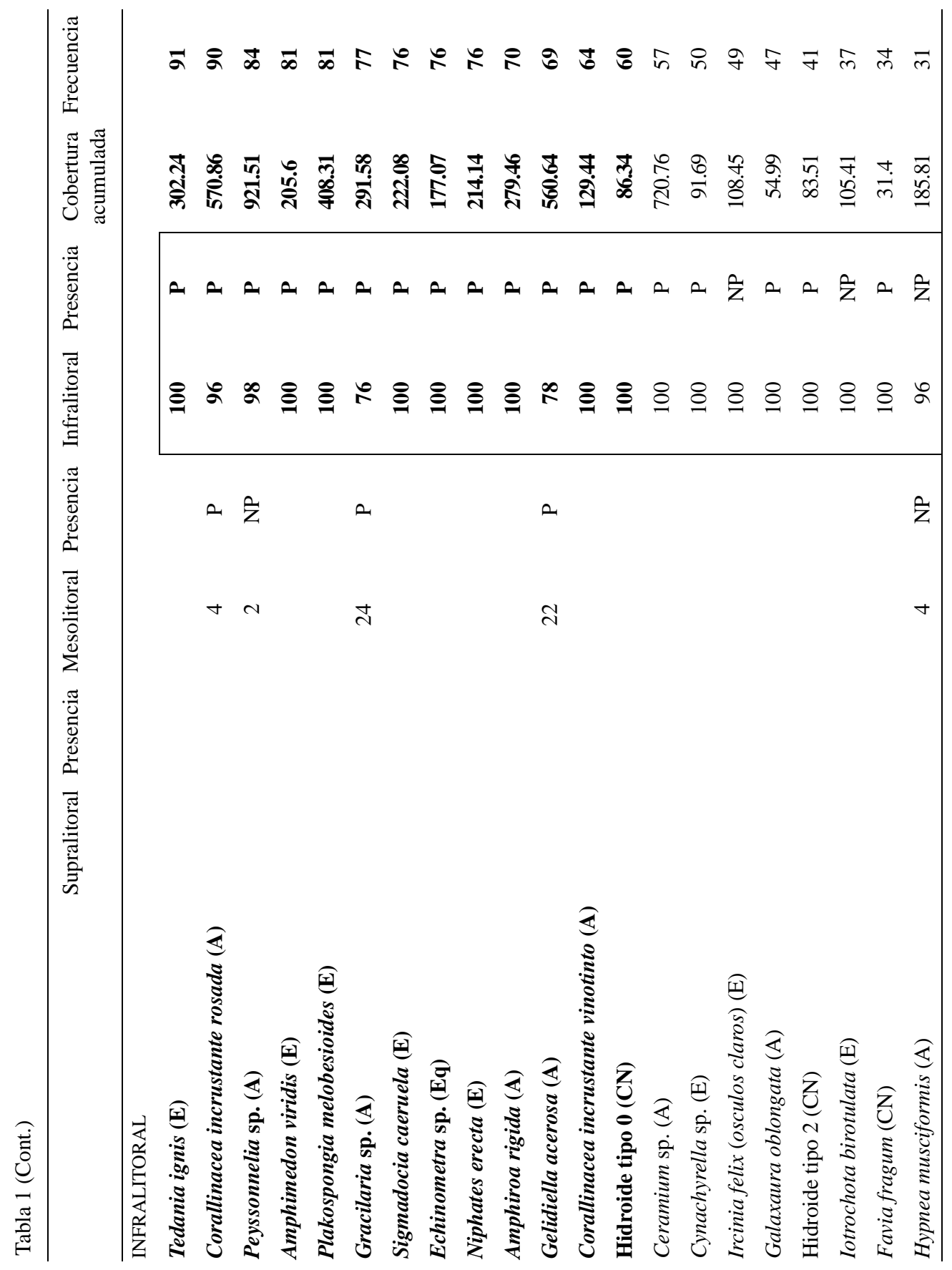


Ciencias Marinas, Vol. 25, No. 4, 1999

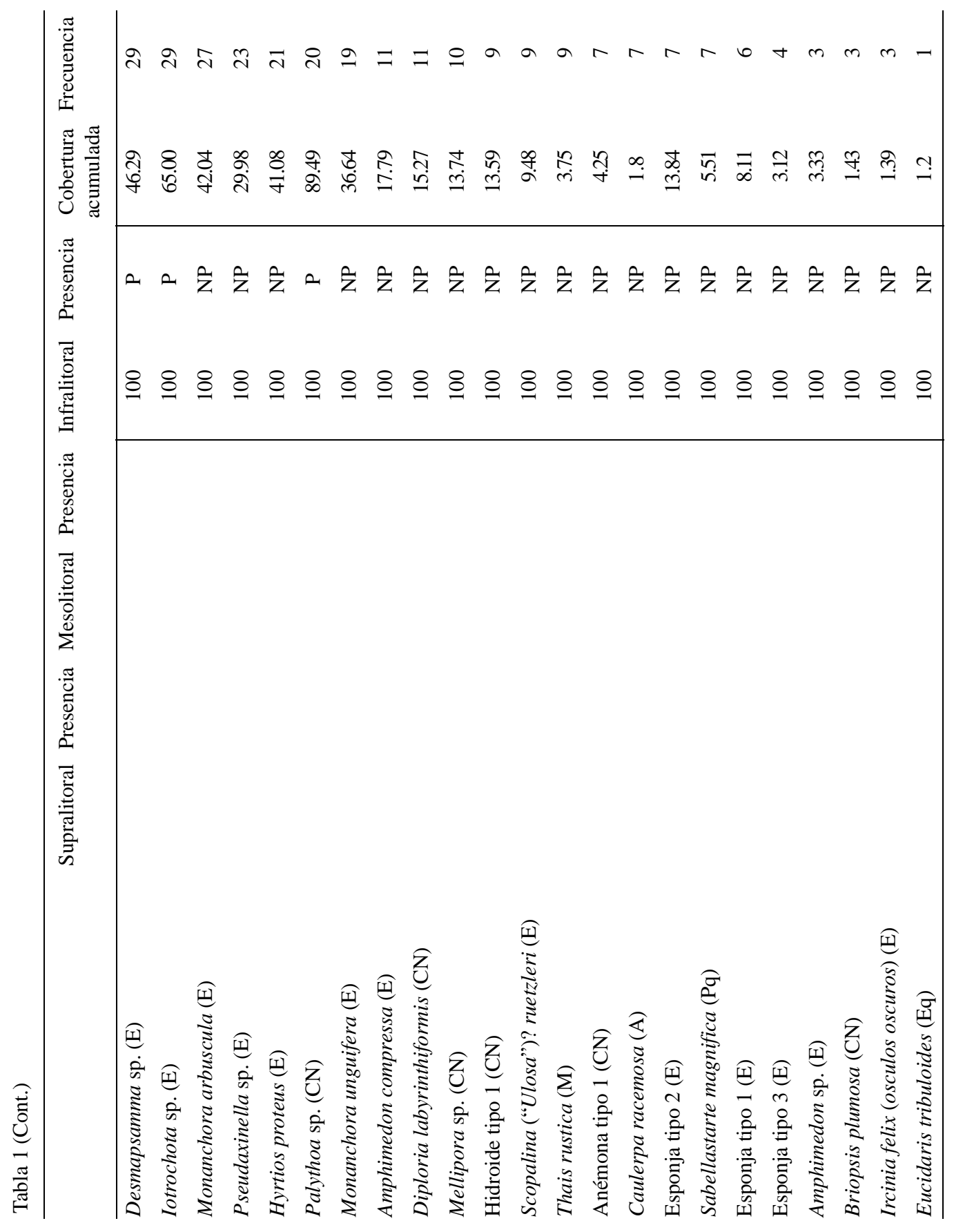


tanto que las especies con una baja frecuencia (no permanentes $[\mathrm{NP}])$ presentan un comportamiento temporal variable. Se observa también como las especies características de una zona pueden temporalmente ocupar las zonas adyacentes, por ejemplo: Dendropoma sp. en el mesolitoral; y Tedania ignis (Duchassaing y Micheloti, 1864), coralinácea rosada incrustante, Peyssonnelia sp., Amphimedon viridis Duchassaing y Micheloti, 1864 y Plakospongia melobesioides (Ellis y Solander, 1786) en el infralitoral.

\section{Régimen de disturbio}

En el transcurso del monitoreo resultó claro que el disturbio propio del sistema litoral en estudio tuvo su expresión en el cambio del ancho de las zonas.

Al graficar el ancho por transecto de cada zona en los muestreos (fig. 3), se encontró una variación promedio de $1178 \pm 342 \mathrm{~cm}$ para el infralitoral, de $607 \pm 351 \mathrm{~cm}$ para el supralitoral y de $100 \pm 32.5 \mathrm{~cm}$ para el mesolitoral. Las longitudes más variables entre los transectos fueron, en su orden: el supralitoral, coeficiente de variación (cv) $=0.58$; mesolitoral, $\mathrm{cv}=0.35$; e infralitoral, $\mathrm{cv}=0.29$.

La variación del ancho del supralitoral obedece en principio a la migración del límite superior del mesolitoral, mientras que la variación del ancho del infralitoral es debida, en su límite superior, a la migración del límite inferior del mesolitoral y, en su límite inferior, a eventos de invasión y retirada de sedimentos arenosos sobre el sustrato rocoso. La poca longitud del mesolitoral es el resultado de la pequeña amplitud de la marea.

La acción del viento y el oleaje pueden ser los responsables del cambio del límite superior del supralitoral y de la migración del mesolitoral. En la época seca se debería producir un desplazamiento del mesolitoral hacia el supralitoral como respuesta a la mayor humectación causada por un incremento en la acción del viento y oleaje; en contraste, en la época de lluvias, cuando los vientos y la humectación disminuyen, se presentaría un aumento del ancho del supralitoral. lower limit of the mesolittoral and the invasion and removal of sandy sediments on the rocky bottom in the upper and lower limits of the infralittoral, respectively. The short length of the mesolittoral is the result of the small tide amplitude.

The wind and wave action may be responsible for the change in the upper limit of the supralittoral and for the migration of the mesolittoral. In the dry season, there should be a displacement of the mesolittoral towards the supralittoral in response to higher humidity caused by the increase in wind and wave action; however, during the rainy season, when the winds and humidity decrease, the width of the supralittoral should increase.

The pattern of change observed does not correspond directly to that expected. The length of the supralittoral for transects 1,2,3, 4 and 6 changes as expected (an average decrease in width of $180 \mathrm{~cm}$ ), whereas for transects 7,8 and 10 , the width of the supralittoral remained relatively constant in time, and the pattern for transects 5 and 9 was opposite that expected, with greater widths of the supralittoral during the dry season than during the rainy season.

In order to explain the migration dynamics of the mesolittoral (and the change in width of the supralittoral) more elements must be included than just the wind regimen. The effect of the wind is undoubtedly mediated and modified by the orientation of the littoral, and by the profile of the transects that affects the wave energy and the mean changes in sea level.

Based on the fact that the width of the infralittoral is generally greater during the dry season, and that the invading sediment is made up of coarse sands similar to those found on the sandy plane located near the rocky shore, it can be assumed that the variation of the lower limit of the infralittoral by the invasion and removal of sediments is more likely the result of the wind regimen mediated by topographic factors than of the supply of sediments from Cartagena Bay.

It is interesting to note how the disturbance regimen manifested can be so heterogeneous at a relatively small site (200 m long). 


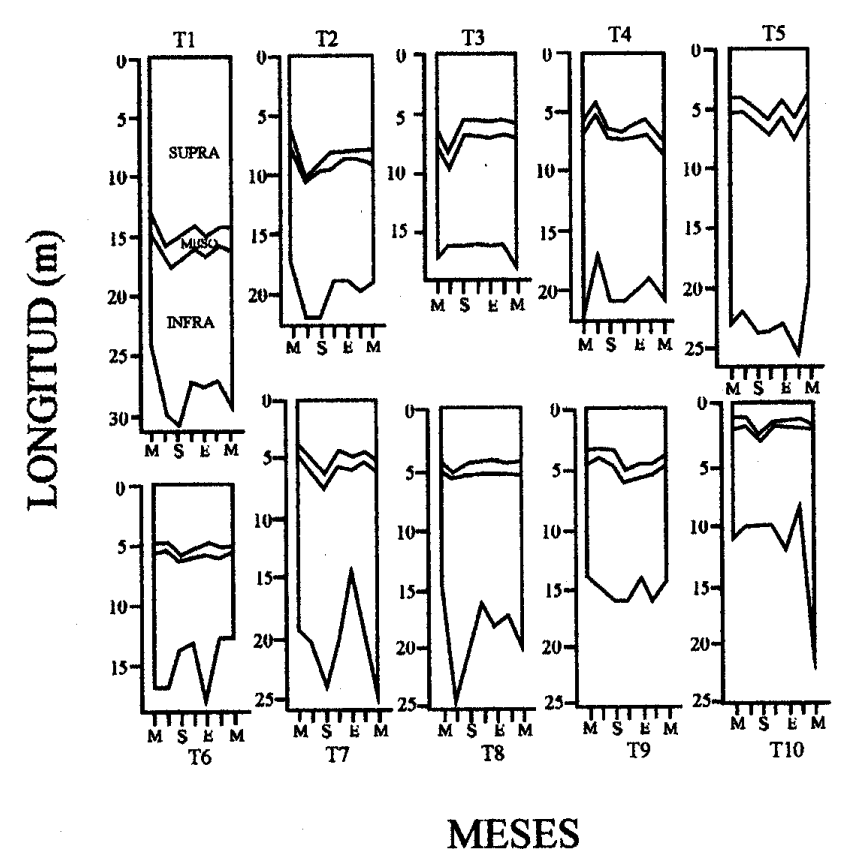

Figura 3. Variación temporal del ancho (metros) de las zonas supralitoral (SUPRA), mesolitoral (MESO) e infralitoral (INFRA) en cada uno de los transectos (1 a 10) a lo largo del tiempo de muestreo.

Figure 3. Temporal variation of the width (meters) of the supralittoral (SUPRA), mesolittoral (MESO) and infralittoral (INFRA) zones in each of the transects (1 to 10) throughout the study period.

El patrón de cambio encontrado no correspondió estrictamente con lo esperado. Se encontró que la longitud del supralitoral para los transectos 1, 2, 3, 4 y 6 cambia con el patrón esperado (una disminución en el ancho de $180 \mathrm{~cm}$ en promedio), en tanto que en los transectos 7,8 y 10 el ancho del supralitoral permaneció relativamente constante en el tiempo, y en los transectos 5 y 9 el patrón fue contrario al esperado, con anchos del supralitoral mayores en la época seca que en la de lluvias.

La explicación a la dinámica de migración del mesolitoral (y de cambio del ancho del supralitoral) debe incluir entonces más elementos que el simple régimen de vientos. Sin duda su efecto es mediado y modificado por la orientación del litoral a los mismos, y al perfil de los transectos

\section{Spatial pattern}

Figure 4 shows the NMDS ordination of the ten transects per sampling date. Transect 10 presents an independent behavior in all sampling dates; however, the groups formed by the other transects suggest the existence of an environmental gradient (possibly exposure to wind and waves) in the direction of the numeration of the transects (1 to 9), modulated by the mosaic effect that consists of the biological heterogeneity resulting from the spatial heterogeneity (different profile and length of the transects), which can create microhabitats, and of the unequal impact of the disturbance regimen on the transect.

Transect 10 is a special case. Here, many factors converge and make it different from the 

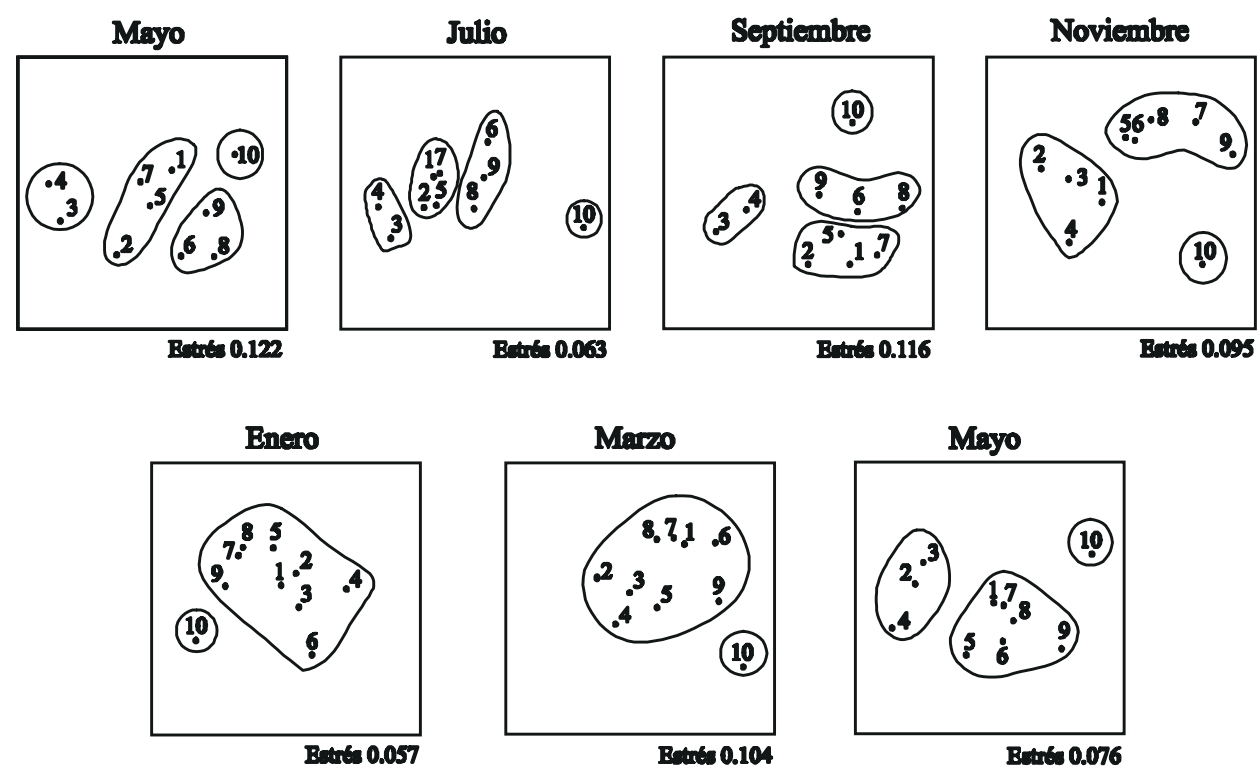

Figura 4. Análisis de ordenación no métrica multidimensional (NMDS) de los 10 transectos en cada mes de muestreo.

Figure 4. Nonmetric multidimensional scaling (NMDS) analysis of the 10 transects in each sampling month.

que afecta la energía de las olas y los cambios medios en el nivel del mar.

El hecho de que en promedio se encuentra un ancho mayor en el infralitoral en la época seca y el que el sedimento invasor esté conformado por arenas gruesas similares a las encontradas en la planicie arenosa ubicada al frente del litoral rocoso, llevan a suponer que la variación del límite inferior del infralitoral debido a la invasión y retirada de sedimentos puede ser debida más al régimen de vientos mediado por factores topográficos, que por el aporte de sedimentos provenientes de la Bahía de Cartagena.

Es importante resaltar como en un sitio relativamente pequeño (200 $\mathrm{m}$ de longitud) la manifestación del régimen de disturbio puede ser tan heterogénea.

\section{Patrón espacial}

La figura 4 muestra el ordenamiento NMDS de los diez transectos en cada fecha de muestreo. other transects; first, by the pronounced slope with an almost vertical inclination and second, by its location that allows the waves and currents to have a greater influence. The most notable consequence of the above characteristics is a greater predominance of sponges than of algae relative to transects 1 to 9 .

\section{Temporal pattern}

Figure 4 shows that the NMDS ordination of the transects determined for the first sampling date (May) remains basically the same until the third sampling (September). By the fourth sampling (November) a rearrangement of the littoral community has occurred (e.g., transects 1 and 7 have separated and form part of different groups). The rearrangement continues in the subsequent samplings (January, March and May of the following year).

The classification and ordination analyses of the sampling dates (an assembly of the transects 
Ciencias Marinas, Vol. 25, No. 4, 1999

El transecto 10 presenta un comportamiento independiente en todas las fechas de muestreo; sin embargo, los grupos formados por los otros transectos sugieren la existencia de un gradiente ambiental (posiblemente de exposición al viento y oleaje) en el sentido de la numeración de los transectos (1 a 9), modulado por el efecto de mosaico que consiste en la heterogeneidad biológica como producto de la heterogeneidad espacial (diferente perfil y largo de los transectos), que puede crear microhábitats, y del desigual impacto sobre los transectos del régimen de disturbio.

Un caso especial lo constituye el transecto 10. En este transecto se conjugan varios factores que lo diferencian de los demás transectos. Primero, la pendiente pronunciada con una inclinación casi vertical y segundo, su ubicación espacial que hacen de este transecto un punto de mayor influencia de oleaje y corrientes. La consecuencia más conspicua de las anteriores características es el reemplazo del predominio de las algas por esponjas en este transecto respecto a las transectos 1 a 9.

\section{Patrón temporal}

La figura 4 muestra que el ordenamiento NMDS de los transectos determinado para la primera fecha de muestreo (mayo) se mantiene en principio hasta el tercer muestreo (septiembre). Para la fecha del cuarto muestreo (noviembre) ha ocurrido un reacomodamiento de la comunidad litoral (por ejemplo, los transectos 1 y 7 se han separado y forman parte de grupos diferentes). El reacomodamiento continúa en las siguientes fechas (enero, marzo y mayo del siguiente año).

Al observar los análisis de clasificación y ordenación de las fechas de muestreo (reuniendo la información de los transectos por fecha) (fig. 5), se encuentra un desplazamiento escalonado de la comunidad del muestreo de mayo al de noviembre, mientras que los muestreos de enero, marzo y mayo conforman un grupo separado. Estas observaciones sugieren la existencia de una respuesta global de la comunidad litoral al régimen climático y de disturbio, ya que los by date) (fig. 5) establish a graded displacement of the community of the May sampling towards the November sampling, whereas the January, March and May samplings make up a separate group. These observations suggest a global response of the littoral community to climate and disturbance, since the May to November samplings correspond to the rainy season and the January to May samplings to the dry season.

The first and last samplings correspond to the same month (May), but with a difference of one year (1993 to 1994). It is evident that the littoral community did not present the same structure of the previous year. The mosaic underwent recycling and after one year it has a new configuration. Due to the temporal scale of the study (one year), it is difficult to say if the littoral community as a whole would change during a longer period that included more environmental cycles, as has been detected for other shores (Hartnoll and Hawkins, 1980).

\section{ACKNOWLEDGEMENTS}

We thank Captain Francisco Arias-Isaza, director of INVEMAR, for his support; Sven Zea, Néstor Campos, Juan Manuel Díaz and Guillermo Díaz-Pulido for their help with confirming some species; and the personnel of the Marine Organism Reference collection of INVEMAR. Contribution No. 625 of INVEMAR.

English translation by Jennifer Davis.

muestreos de mayo a noviembre corresponden a la estación lluviosa y los muestreos de enero a mayo corresponden a la estación seca.

El primero y último muestreo corresponden al mismo mes (mayo) con un año de diferencia (1993 a 1994). Evidentemente la comunidad litoral no regresó exactamente a la misma estructura del año anterior. El mosaico sufrió reciclamiento y un año después muestra una nueva configuración. Debido a la escala temporal del estudio (un año), es difícil decir si la comunidad litoral en conjunto cambia 

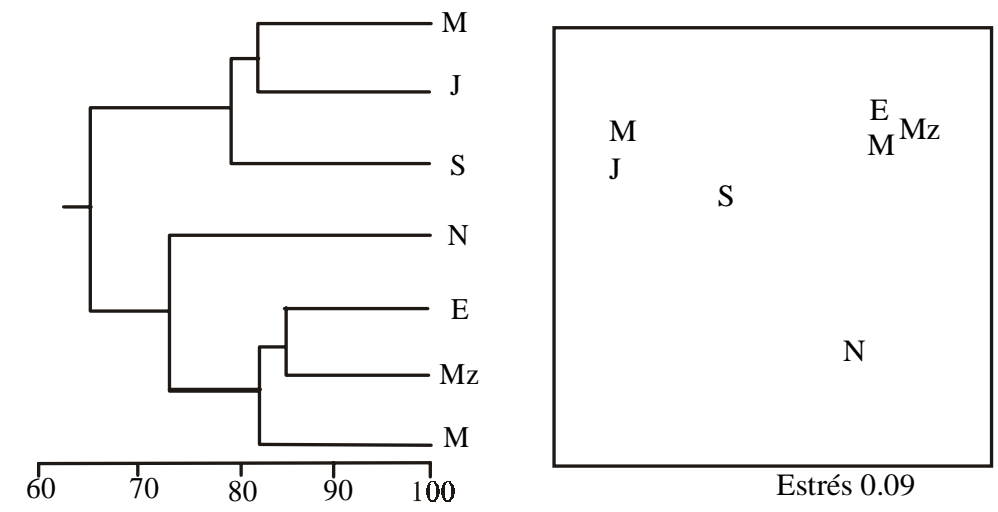

Figura 5. Análisis de clasificación empleando el índice de similaridad de Bray-Curtis y ordenación no métrica multidimensional (NMDS) de los meses de muestreo.

Figure 5. Classification analysis using the Bray-Curtis similarity index and nonmetric multidimensional scaling (NMDS) of the sampling months.

en un periodo mayor en seguimiento de ciclos ambientales mayores, como ha sido detectado en otros litorales (Hartnoll y Hawkins, 1980).

\section{AGRADECIMIENTOS}

Al Capitán de Fragata, Francisco Arias-Isaza, director del INVEMAR, por su apoyo. A Sven Zea, Néstor Campos, Juan Manuel Díaz y Guillermo Díaz-Pulido por su ayuda en la confirmación de algunas especies. Al personal de la Colección de Referencia de Organismos Marinos del INVEMAR. Contribución número 625 del INVEMAR.

\section{REFERENCIAS}

Baker, J.M. and Crothers, J.M. (1987). Intertidal Rock. In: J. Baker and W. Wolff (eds.), Biological Surveys of Estuarine Coasts. Cambridge Univ. Press, pp. 157-197.

Bandel, K. and Wedler, E. (1987). Hydroid, amphineuran and gastropod zonation in the littoral of the Caribbean Sea, Colombia. Senckenbergiana Marit., 19(1/2): 1-129.

Boero, F. and Fresi, E. (1986). Zonation and evolution of a rocky bottom hydroid community. Mar. Ecol., 7(2): 123-150.
Brattström, H. (1980). Rocky shore zonation in the Santa Marta area, Colombia. Sarsia, 65: 163-226.

Bula, G. (1977). Algas marinas bénticas indicadoras de un área afectada por surgencia frente a la costa Caribe de Colombia. An. Inst. Inv. Mar. Punta de Betín, (9): 17-44.

Bula, G. (1985). Un núcleo nuevo de surgencia en el Caribe colombiano detectado en correlación con las macroalgas. Bot. Ecot.: Ecos. Trop., (12): 2-20.

CARICOMP (Caribbean Coastal Marine Productivity) (1990). Manual of methods for mapping and monitoring of physical and biological parameters in the coastal zone of the Caribbean. Florida Institute of Oceanography, $35 \mathrm{pp}$.

Clarke, K. and Warwick, R. (1994). Change in marine communities: an approach to statistical analysis and interpretation. Natural Environment Research Council, UK, 144 pp.

Díaz, J.M. y Puyana, M. (1994). Moluscos del Caribe Colombiano. COLCIENCIAS-FUNDACIÓN NATURA-INVEMAR. Ed. Presencia, Santafé de Bogotá, $291 \mathrm{pp}$

Eston, V.R., Migotto, A.E., de Oliveira Filho, E.C., de Almeida Rodriguez, S. and Freitas, J.C. (1986). Vertical distribution of benthic marine organisms on rocky coasts of Fernando de Noronha Archipelago (Brazil). Bol. Inst. Ocenogr., 34: 37-53.

Foster, M., Harrold, C. and Hardin, D.D. (1991). Point vs photo quadrat estimates of the cover of sessile 
Ciencias Marinas, Vol. 25, No. 4, 1999

marine organisms. J. Exp. Mar. Biol. Ecol., 146: 193-203.

Gaviria, S. (1977). Observaciones de los períodos de reproducción y ecología de algunas algas marinas del Caribe colombiano, incluyendo la evaluación bromatológica de seis especies. Tesis, Universidad Jorge Tadeo Lozano, Bogotá, Colombia, 152 pp.

Guillot, G. y Márquez, G. (1978). Estudios de la vegetación béntica marina del parque Nacional Tayrona, costa Caribe colombiana. I. Relaciones vegetación-zonación-sustrato. An. Inst. Inv. Mar. Punta de Betín, 10: 133-148.

Gutiérrez, J.C. (1994). Inventario preliminar de los moluscos bentónicos de la costa occidental de la Isla de Tierra Bomba, Caribe colombiano. Tesis, Universidad Jorge Tadeo Lozano, Bogotá, Colombia, $441 \mathrm{pp}$

Hartnoll, R.G. and Hawkins, S.J. (1980). Monitoring rocky-shore communities: a critical look at spatial and temporal variation. Helgoländer Meeresunters., 33: 484-494.

Hill, A.S. and Hawkins, J. (1991). Seasonal and spatial variation of epilithic microalgal distribution and abundance and its ingestion by Patella vulgata on a moderately exposed rocky shore. J. Mar. Biol., 71: 403-423.

HIMAT (1995). Boletín Meteorológico. Bogotá, $227 \mathrm{pp}$.

Hoeck, C. van, Dreeman, A.M., Bak, R.P.M. and von Buurt, G. (1978). The distribution of algae, corals and gorgonians in relation to depth, light attenuation, water movement and grazing pressure in the fringing coral reef of Curaçao, Netherlands Antilles. Aquat. Bot., 5: 1-46.

Kaandorp, J.A. (1986). Rocky substrate communities of the infralittoral fringe of the Boulonnais coast, NW France: a quantitative survey. Mar. Biol., 92: 255-265.

Le Blé, S. y Cuignon, R. (1987). El archipiélago de las islas del Rosario: estudio morfológico, hidrodinámico y sedimentológico. Bol. Cient. $\mathrm{CIOH}$, Cartagena (Colombia), 7: 37-52.

Márquez, G. y Guillot, G. (1983). La vegetación marina del Parque Nacional Tayrona, costa Caribe colombiano. II. Tipos de vegetación. An. Inst. Inv. Mar. Punta de Betín, 13: 17-51.

Meese, R.J. and Tomich, P.A. (1992). Dots on the rocks: a comparison of percent cover estimation methods. J. Exp. Mar. Biol. Ecol., 165: 59-73.
Ojeda, F. and Dearborn, J.H. (1989). Community structure of macroinvertebrates inhabiting the rocky subtidal zone in the Gulf of Maine: seasonal and bathymetric distribution. Mar. Ecol. Prog. Ser., 57: 147-161.

Plagiardini, J.L., Gómez, M., Gutiérrez, H., Zapata, S., Jurado, A., Garay, J. y Vernette, G. (1982). Síntesis del proyecto Bahía de Cartagena. Bol. Cient. $\mathrm{CIOH}$, Cartagena (Colombia), 4: 49-110.

Prahl, H. von y Erdhardt, H. (1985). Colombia: Corales y Arrecifes Coralinos. FEN, Bogotá, 295 pp.

Rogers, C., Garrison, G., Grober, P., Hillis, Z. and Frake, M. (1994). Coral reef monitoring manual for the Caribbean and western Atlantic. National Park Service, Virgin Islands National Park, 7 pp.

Schoppe, S. (1990). La asociación entre Acyrtus rubiginosus (Gobiosocidae), Clastotoechus vanderhorsti (Porcellanidae), Ophiotrix sp. (Ophiotrichidae) y su huesped perforador de roca Echinometra lucunter (Echinometridae) en el litoral rocoso de Santa Marta, Colombia. Tesis, Institut für Allgemeine und Spezielle Zoologie, Justus-Liebig-Universität, Giesen, 11 pp.

Schoppe, S. (1996). The boreholes of the sea urchin genus Echinometra (Echinodermata: Echinoidea: Echinometridae) as a microhabitat in tropical South America. PSZNI: Mar. Ecol., 17(1-3): 181-186.

Stephenson, T. and Stephenson, A. (1949). The universal features of zonation between tide-marks on rocky coasts. J. Ecol., 37: 289-305.

Taylor, J.D. (1978). Zonation of rocky intertidal surfaces. Chapter 12. In: Coral Research Methods, UNESCO, Paris, pp. 139-140.

Thomas, M.L. (1985). Littoral community structure and zonation on the rocky shores of Bermuda. Bull. Mar. Sci., 37(3): 857-870.

Vegas-Vélez, M. (1971). Introducción a la ecología del bentos marino. OEA, Washington DC, Monografía No. 13, 91 pp.

Zea, S. (1987). Esponjas del Caribe Colombiano. Ed. Catálogo Científico. FEN, Bogotá, 286 pp.

Zea, S. (1993a). Cover of sponges and other sessile organisms in rocky and coral reef habitats of Santa Marta, Colombian Caribbean Sea. Carib. J. Sci., 29: $1-2$.

Zea, S. (1993b). Recruitment of desmosponges (Porifera, Desmospongiae) in rocky and coral reef habitats of Santa Marta, Colombian Caribbean. PSZNI: Mar. Ecol., 14(1): 1-21. 